\title{
PEMBERIAN ES KRIM UBI JALAR UNGU BERPENGARUH TERHADAP KADAR KOLESTEROL TOTAL DAN TEKANAN DARAH PASIEN HIPERKOLESTEROLEMIA
}

\author{
Dwita Arisetia, Emy Yuliantini, Kusdalinah \\ Politeknik Kesehatan Kementerian Kesehatan Bengkulu, Program Studi D-IV Gizi \\ arisetia09@gmail.com
}

\begin{abstract}
Hypercholesterolemia is one of the causes of cardiovascular disease. Epidemiologic studies have shown a correlation between elevated total cholesterol levels, especially LDL cholesterol with CHD events, low of cholesterol cab decrease the risk of cardiovascular disease and cholesterol abnormal can increase the risk of hypertension. This study aims to determine the effect of purple sweet potato ice cream on total cholesterol levels and blood pressure in hypercholesterolemi apatients. The research design was pre-experimental with one group pretest-posttest method. The sample in this study were 30 people who met the inclusion criteria. The intervention was given is $60 \mathrm{gr}$ ( 1 cup) purple sweet potato ice cream per day for 28 days. The data obtained were analyzed using the dependent t-test test. Given the purple sweet potato ice cream has significant improvement in total cholesterol and blood pressure $\mathrm{p}$ value $<0.05$. There's an effect of purple sweet potato ice creamon total cholesterol levels and blood pressure in hypercholesterolemia apatients at Basuki Rahmad community health.
\end{abstract}

Keywords: Anthocyanin, Blood Pressure, Hypercholesterolemia, Purple Sweet Potato, Total Cholesterol.

\begin{abstract}
Abstrak: Hiperkolesterolemia merupakan salah satu penyebab dari penyakit kardiovaskular. Studi epidemiologi membuktikan ada hubungan antara peningkatan kadar kolesterol total, khususnya kolesterol LDL dengan kejadian PJK, penurunan kadar kolesterol dapat menurunkan resiko kejadian kardiovaskular dan kolesterol yang tidak normal meningkatkan resiko hipertensi. Penelitian ini bertujuan untuk mengetahui pengaruh pemberian es krim ubi jalar ungu terhadap kadar kolesterol total dan tekanan darah pada pasien hiperkolesterolemia.Desain penelitian ini adalah Pra-eksperimental dengan metode one group pretest-posttest. Sampel dalam penelitian ini sebanyak 30 orang yang memenuhi kriteria inklusi. Intervensi yang diberikan adalah pemberian es krim ubi jalar ungu sebanyak 60 gr $(1$ cup) per hari selama 28 hari. Data yang didapat dianalisa menggunakan uji t-test dependen. Pemberian es krim ubi jalar ungu berpengaruh secara signifikan terhadap kadar kolesterol total dan tekanan darah dengan nilai $p<0,05$. Ada pengaruh pemberian es krim ubi jalar ungu terhadap kadar kolesterol total dan tekanan darah pada pasien hiperkolesterolemia di Puskesmas Basuki Rahmat.
\end{abstract}

Kata Kunci : Antosianin, Hiperkolesterolemia, Kolesterol Total, Tekanan Darah, Ubi Jalar Ungu.

Penyakit tidak menular (PTM) merupakan penyakit yang tidak ditularkan dari orang ke orang yang perkembangannya umumnya lambat. Terdapat empat jenis PTM utama menurut World Health Organization (WHO) (2015) yaitu: penyakit kardiovaskular (penyakit jantung koroner
(PJK), stroke), kanker, penyakit pernafasan kronis (asma, penyakit paru obstruksi kronis), dan diabetes (DM). Hiperkolesterolemia merupakan salah satu penyebab dari penyakit kardiovaskular.Studi epidemiologi telah membuktikan bahwa ada hubungan antara 
peningkatan kadar kolesterol total, khususnya kolesterol LDL dengan kejadian PJK. Penurunan kadar kolesterol sebanyak $1 \%$ dapat menurunkan resiko penyakit kardiovaskular sebanyak 2\% (Sari et al. 2014).

Asupan tinggi serat akan menurunkan resiko terjadinya peningkatan glukosa dalam darah, dan kolesterol total. Semakin rendah asupan serat maka akan semakin tinggi kadar kolesterol total (Bintanah dan Handarsari2012). Berdasarkan data dari International Institute of Tropical Agriculture dalam Samber et al.(2013) menunjukkan bahwa, kandungan serat kasar pada ubi jalar ungu adalah 1,2g/100gr, lebih besar jika dibandingkan dengan serat kasar pada ubi jalar putih. Sedangkan kandungan antosianin pada ubi jalar ungu adalah 110,15mg/100gr. Warna ungu pada ubi jalar disebabkan karena adanya zat warna alami antosianin yang berperan sebagai antioksidan.Selain serat kandungan flavonoid dalam tumbuhan juga sangat bermanfaat bagi tubuh kita.

Antosianin adalah salah satu flavonoid yang terdapat didalamubi jalar ungu yang dapat menghambat penyerapan kolesterol di dalam saluran cerna (Dwi et al. 2015).Antosianin dapat menurunkan kadar kolesterol LDL dengan mengaktifkan jalur adenosine-monophospate protein kinase (AMPK) yang menghambat regulasi enzim HMG-KoA reduktase dalam sintesis kolesterol dan menghambat Asetil-KoA Karboksilase (ACC) sehingga menurunkan esterifikasi kolesterol pada usus dan hati. Jika pembentukan kolesterol terhambat maka VLDL tidak akan dihidrolisis dan akan menekan LDL dalam darah (Pil et al. 2011).

Ubi jalar ungu dapat dikembangkan menjadi produk olahan yang bernilai gizi tinggi, salah satunya adalah pengolahan ubi jalar ungu Jepang menjadi bahan baku es krim.Berdasarkan data dari Laboratorium Puskesmas Basuki Rahmad Kota Bengkulu (2016) total jumlah pasien yang memeriksakan kadar kolesterol total pada tahun 2016 sebanyak 256 orang dan 219 orang diantaranya mengalami hiperkolesterolemia. Oleh karena itu peneliti tertarik untuk meneliti tentang pengaruh pemberian es krim ubi jalar ungu terhadap kadar kolesterol total dan tekanan darah pasien hiperkolesterolemia di Puskesmas Basuki Rahmad Kota Bengkulu.

Tujuan dari penelitian ini adalah untuk mengetahui pengaruh pemberian es krim ubi jalar ungu terhadap kadar kolesterol total dan tekanan darah pada pasien hiperkolesterolemia.

\section{BAHAN DAN CARA KERJA}

Penelitian ini menggunakan desain Pra-eksperimental dengan metode one group pretest-posttest. Intervensi yang diberikan adalah pemberian es krim ubi 
jalar ungu sebanyak 60 gr(1 cup) per hari selama 28 hari. Penelitian ini dilakukan di wilayah kerja Puskesmas Basuki Rahmad Kota Bengkulu.

Bahan dan alat yang digunakan dalam penelitian ini adalah susu SKM, air es, maizena,TBM/Sp dan ubi jalar ungu, alat pemeriksa kadar kolesterol total dan tekanan darah digital, stik kolesterol, timbangan, mangkok stainless, baskom plastik, sendok kayu, dandang stockpot, gelas ukur,mixer, ayakan, dan cup es krim.

Proses pembuatan es krim ubi jalar ungu adalah : ubi jalar ungu dicuci bersih lalu dikupas kulitnya, Ubi jalar ungu dipotong melintang dengan ketebalan 2-2,5 $\mathrm{cm}$, Potongan ubi jalar tersebut dicampur dengan air bersih dengan perbandingan 1 kg ubi jalar ditambah air 1 liter, Ubi jalar ungu diblender dan disaring dengan tiga lapis kain kasa, Susu SKM dicampur dengan gula, dan air lalu diaduk diatas api kecil, Tambahkan tepung maizena yang sudah dilarutkan dengan air, Tambahkan sari ubi jalar ungu Jepang kedalam adonan kemudian dituangkan kedalam wadah, Dinginkan dalam freeze.

Data yang digunakan dalam penelitian ini merupakan data primer dan sekunder. Data primer berasal dari hasil pengamatan selama 28 hari penelitian berupa identitas sampel, tekanan darah sampel, dan kadar kolesterol dalam darah sampel. Dan data asupan menggunakan teknik wawancara dan food recall 3x24 jam.Sedangkan data sekunder berupa daftar pemeriksa kadar kolesterol di Puskesmas Basuki Rahmad.

Data yang telah dikumpulkan dianalisis secara bertahap yaitu univariat dengan menggunakan analisis deskriptif dan bivariat dengan menggunakan uji Chi Square kemudian data akan disajikan dalam bentuk tabel.

\section{HASIL}

\section{Analisa Univariat}

Tabel 1 menunjukkan bahwa rata-rata kadar kolesterol mengalami penurunan yaitu masing-masing sebesar 226,43 mg/dl dan setelah diberikan intervensi turun menjadi 224,23 mg/dl. Begitu pula dengan standar deviasi yang semula sebesar 15,11 menjadi 14,56.

Tabel 1 Gambaran Kadar Kolesterol Total Responden Hiperkolesterolemia di Puskesmas Basuki Rahmad

\begin{tabular}{lcccc} 
Variabel & n & Mean \pm SD & Min & Max \\
\hline $\begin{array}{l}\text { Kolesterol } \\
\text { Sebelum }\end{array}$ & 30 & $\begin{array}{c}226,43 \pm \\
15.11\end{array}$ & 205 & 257 \\
& & & \\
$\begin{array}{l}\text { Kolesterol } \\
\text { Sesudah }\end{array}$ & 30 & $\begin{array}{l}224,23 \\
\pm 14.56\end{array}$ & 202 & 247 \\
\hline
\end{tabular}

Tabel 2 Gambaran Tekanan Darah Responden Hiperkolesterolemia di Puskesmas Basuki Rahmad

\begin{tabular}{lcccc}
\hline \multicolumn{1}{c}{ Variabel } & $\mathbf{n}$ & $\begin{array}{c}\text { Mean } \\
\mathbf{\pm} \text { SD }\end{array}$ & Min & Max \\
\hline Tekanan & & 84,73 & & 93 \\
DarahDiastolik & 28 & \pm & 80 & \\
Sebelum & & 3,88 & & \\
Tekanan & & 82,6 & & \\
DarahDiastolik & 28 & \pm & 77 & 91 \\
Sesudah & & 3,84 & & \\
\hline
\end{tabular}


004 Jurnal Media Kesehatan, Volume 12 Nomor 1, Juni 2019, hlm. 001-010

Tabel 3 Gambaran Tekanan Darah Responden Hiperkolesterolemia di Puskesmas Basuki Rahmad

\begin{tabular}{|c|c|c|c|c|}
\hline Variabel & $\mathbf{n}$ & $\begin{array}{l}\text { Mean } \pm \\
\text { SD }\end{array}$ & Min & Max \\
\hline $\begin{array}{l}\text { Tekanan Darah } \\
\text { Diastolik Sebelum }\end{array}$ & 28 & $\begin{array}{l}84,73 \pm \\
3,88\end{array}$ & 80 & 93 \\
\hline $\begin{array}{l}\text { Tekanan Darah } \\
\text { Diastolik Sesudah }\end{array}$ & 28 & $\begin{array}{l}82,6 \pm \\
3,84\end{array}$ & 77 & 91 \\
\hline
\end{tabular}

Tabel 2 menunjukkan bahwa rata-rata tekanan darah sebelum dan sesudah intervensi juga mengalami penurunan yaitu yang semula sebesar 84,73 $\mathrm{mmHg}$ mengalami penurunan menjadi 82,60 mmHg. Dan dengan standar deviasi masing-masing yaitu sebesar 3,88 turun menjadi 3,84.Tabel 3 menunjukkan ratarata asupan serat dan kolesterol responden sebelum dan sesudah diberikan intervensi. Rata-rata asupan serat responden sebelum dan sesudah intervensi adalah 7,1 gr dan 6,0 gr per hari dengan standar deviasi keduanya adalah 1,8. Responden jarang mengkonsumsi buah terutama ketika bulan puasa sehingga konsumsi serat responden menurun meskipun tidak terlalu berbeda selama penelitian berlangsung.

Rata-rata konsumsi kolesterol responden masing-masing mengalami peningkatan dari 212,6 mg naik menjadi 213,6 mg dengan standar deviasi dari 94,6 menjadi 95,5. Hal ini dikarenakan asupan kolesterol responden pada akhir penelitian mengalami peningkatan karena responden memang tidak diberikan diit khusus sehingga asupan makanan tidak dibatasi
Tabel 4 Gambaran Konsumsi Asupan Serat dan Kolesterol Responden Hiperkolesterolemia di Puskesmas Basuki Rahmad

\begin{tabular}{lllll}
\hline Variabel & $\mathbf{n}$ & Mean \pm SD & Min & Max \\
\hline Serat Sebelum & 30 & $7,1 \pm 1,8$ & 3,4 & 11 \\
$\begin{array}{l}\text { Serat Sesudah } \\
\text { Kolesterol }\end{array}$ & 30 & $6,0 \pm 1,8$ & 3,3 & 10,6 \\
$\begin{array}{l}\text { Sebelum } \\
\begin{array}{l}\text { Kolesterol } \\
\text { Sesudah }\end{array}\end{array}$ & 30 & $212,6 \pm 94,6$ & 71,4 & 431 \\
\hline
\end{tabular}

\section{Analisa Bivariat}

Tabel 4 menunjukkan hasil uji statistic t-test dependent antara sebelum dan sesudah diberikan intervensi didapatkan nilai $p$ value $(0,021)<0,05$. Hal ini menunjukkan bahwa adanya perbedaan antara rata-rata kadar kolesterol sebelum dan sesudah diberikan es krim ubi jalar ungu atau dengan kata lain adanya pengaruh pemberian es krim ubi jalar ungu terhadap kadar kolesterol pada responden dengan hiperkolesterolemia

Tabel 5 Hasil Uji Statistik Kadar Kolesterol Sebelum dan Sesudah diberikan Intervensi

\begin{tabular}{lccc}
\hline \multicolumn{1}{c}{ Variabel } & $\mathbf{n}$ & Mean \pm SD & $p$ \\
\hline $\begin{array}{l}\text { Kolesterol } \\
\text { Sebelum }\end{array}$ & 30 & $\begin{array}{c}226,433 \pm 15, \\
1\end{array}$ & \\
$\begin{array}{l}\text { Kolesterol } \\
\text { Sesudah }\end{array}$ & 30 & $224,233 \pm 14$, & 0,021 \\
$\begin{array}{l}\text { Kolesterol } \\
\text { Kon }\end{array}$ & 30 & $2,2 \pm 3,03$ & \\
\hline
\end{tabular}

Tabel 5 meunjukkan hasil uji statistic $t$ test dependent antara sebelum dan sesudah intervensi didapatkan nilai $p$ value $(0,001)$ $<0,05$. Hal ini menunjukkan bahwa adanya perbedaan antara rata-rata tekanan darah responden sebelum dan sesudah diberikan 
intervensi atau dengan kata lain adanya pengaruh pemberian es krim ubi jalar ungu terhadap tekanan darah pada responden dengan hiperkolesterolemia.

Tabel 6 Hasil Uji Statistik Tekanan Darah Sebelum dan Sesudah diberikan Intervensi

\begin{tabular}{lccc}
\hline \multicolumn{1}{c}{ Variabel } & n & Mean \pm SD & $p$ \\
\hline $\begin{array}{l}\text { Tekanan Darah } \\
\text { Diastolik Sebelum }\end{array}$ & 28 & $84,73 \pm 3,88$ & \\
$\begin{array}{l}\text { Tekanan Darah } \\
\text { Diastolik Sesudah }\end{array}$ & 28 & $82,60 \pm 3,84$ & 0,001 \\
$\begin{array}{l}\Delta \text { Tekanan Darah } \\
\text { Diastolik }\end{array}$ & 28 & $2,13 \pm 3,03$ & \\
\hline
\end{tabular}

Es krim ubi jalar ungu dibuat menggunakan bahan-bahan yang sangat mudah ditemui dipasaran seperti susu kental manis, maizena, gula pasir, SP/TBM yang digunakan sebagai pengembang dan dengan penambahan sari dari ubi jalar ungu. Pembuatan es krim ubi jalar ungu ini didasari pada penelitian yang dilakukan oleh Mikasari (2011) dan dilakukan sedikit modifikasi yaitu pengubahan bubuk es krim yang diganti dengan tepung maizena, dan pengubahan dosis penambahan ubi jalar ungu.

Kelebihan dari produk es krim ubi jalar ungu ini sendiri terletak pada dosis ubi jalar ungu yang disesuaikan dengan penelitian yang dilakukan oleh Budiasa dan jawi (2011) yang meneliti tentang ekstrak ubi jalar ungu terhadap profil lipid pada kelinci. Dalam penelitian ini, penambahan sari ubi jalar ungu disesuaikan dengan berat badan responden.
Rata-rata konsumsi makanan yang mengandung kolesterol mengalami peningkatan dari 212,6 mg menjadi 213,6 meskipun masih berada pada batas normal. Menurut Mahan \& Escott-Stump(2008) dalam Waloya (2013) batas anjuran konsumsi kolesterol dalam makanan per hari yaitu $\leq 300 \mathrm{mg} /$ hari. Sehingga rata-rata asupan kolesterol responden baik sebelum maupun sesudah intervensi masih berada pada batas yang dianjurkan. Telah disebutkan bahwa salah satu faktor resiko terjadinya hiperkolesterolemia adalah pola konsumsi makanan yang mengandung lemak (Bintanah dan Muryati, 2010). Dalam penelitian ini responden banyak mengkonsumsi telur yang kandungan kolesterolnya sebanyak 467 mg untuk ayam kampung dan 329 mg untuk ayam broiler(Saidin, 2000).

\section{Pengaruh Pemberian Es Krim Ubi Jalar Ungu Terhadap Kadar Kolesterol Total}

Hasil analisa bivariat dengan menggunakan uji t-test dependent terhadap 30 responden menunjukkan bahwa rata-rata kadar kolesterol responden sebelum diberikan es krim ubi jalar ungu adalah $226,43 \mathrm{mg} / \mathrm{dl}$ dengan standar deviasi 15,1 dan sesudah diberikan es krim ubi jalar ungu menjadi $224,23 \mathrm{mg} / \mathrm{dl}$ dengan standar deviasi 14,6. Hasil analisa bivariat diketahui bahwa nilai $\Delta$ atau selisih sebelum dan sesudah diberikan intervensi 
adalah sebesar 2,2 $\mathrm{mg} / \mathrm{dl}$ atau sebesar $0,97 \%$.

Hasil penelitian ini menunjukkan perbedaan jika dibandingkan dengan hasil penelitian Noer dan Budiatmaja (2014) yang meneliti hal serupapada pria dengan hiperkolesterolemia selama 21 hari bahwa terdapat penurunan kadar kolesterol total sebanyak $5,8 \%$ atau sebesar $-13,53 \mathrm{mg} / \mathrm{dl}$. Namun demikian berdasarkan hasil uji $t$ test dependent terjadi penurunan yang bermakna yaitu nilai $p$ value $0.021<0.05$ yang berarti ada pengaruh pemberian es krim ubi jalar ungu terhadap kadar kolesterol total pasien hiperkolesterolemia.

Penelitian yang dilakukan oleh Budiasa dan Jawi (2011) menunjukkan hal yang sama. Mereka melakukan penelitian pada hewan coba kelinci yang diberikan makanan tinggi kolesterol dan ekstrak air ubi jalar ungu. Pada akhir penelitian terjadi penurunan kadar kolesterol yang signifikan $(\mathrm{p}<0,05)$ pada kelinci yang diberikan makanan tinggi kolesterol. Diperkuat juga dengan penelitian Setyaningsih dan Pramono (2013) yang membuktikan bahwa terdapat penurunan kadar kolesterol LDL yang bermakna $(\mathrm{p}=0,049)$ pada kelompok yang diberikan snack bar dengan campuran ubi jalar ungu.

Antosianin yang terkandung didalam ubi jalar ungu dapat menurunkan kadar kolesterol LDL dengan mengaktifkan jalur adenosine-monophosphate protein kinase
(AMPK) yang menghambat regulasi enzim HMG-Koa reduktase dalam sintesis kolesterol dan menghambat Asetil-KoA Karboksilase (ACC) sehingga menurunkan esterifikasi kolesterol pada usus dan hati. Jika pembentukan kolesterol terhambat maka VLDL tidak akan dihidrolisis dan akan menekan LDL dalam darah (Pil dkk, 2011).

Antosianin mengaktifkan AMPK yang diinduksi fosforilasi signifikan ACC (AntiAcetyl-coA Carboxylase) dan diregulasi PPARa (Peroxisome Proliferator-Activated Reseptor $\alpha$ ) dan ACO (Acetyl-coA Carboxylase) dalam hati sehingga meningkatkan penurunan kadar lemak. Sebaliknya, berdasarkan penelitian Trinidad,dkk (2013) pada 59 remaja selama 90 hari, ubi jalar ungu tidak menurukan kadar kolesterol serum totalnya.

Kandungan serat kasar pada ubi jalar ungu juga lebih tinggi jika dibandingkan dengan ubi jalar putih (Samber dkk, 2013). Hal ini sesuai dengan teori yang menyatakan bahwa asupan serat yang tinggi dapat menurunkan kolesterol. Dalam penelitian yang dilakukan oleh Dewi (2015) menyebutkan bahwa asupan serat yang dianjurkan bagi orang dewasa paling sedikit sebanyak 10-13 g/1000 kalori. Anjuran konsumsi serat per orang per hari adalah 25-30 g/hari, berdasarkan anjuran FDA (Food and Drug Association) maupun ADA (American Dietetic Association). Hal 
ini menunjukkan masih kurangnya asupan serat responden jika dibandingkan dengan anjuran konsumsi serat menurut FDA maupun ADA(Bintanah dan Handarsari, 2012).

Penelitian yang dilakukan Estruch,dkk (2009) menyebutkan responden dengan diet tinggi serat menunjukkan adanya peningkatan kadar kolesterol LDL yang bermakna $(\mathrm{p}=0.02)$. Penelitian Noer dan Budiatmaja (2014) pada kelompok yang diberikan jus buah naga dengan kandungan antosianin dan serat juga menunjukkan terjadinya penurunan kadar kolesterol total sebesar $5,8 \%$. Serat dapat menunda pengosongan lambung sehingga rasa kenyang menjadi lama akibatnya asupan kalori menjadi berkurang. Pada saat ini sekresi insulin akan berkurang dan diikuti dengan penghambatan kerja enzim HMGKoA reduktase sehingga sintesis kolesterol menurun (Turner dan Lupton, 2011).

Serat juga diketahui dapat mengikat asam empedu dan meningkatkan pengeluarannya melalui feses. Garam empedu yang telah terikat pada serat tidak dapat direabsorpsi kembali melalui siklus enterohepatik dan akan disekresi melalui feses, akibatnya terjadi penurunan jumlah garam empedu yang menuju kehati. Penurunan ini akan meningkatkan pengambilan kolesterol dari darah untuk disintesis kembali menjadi garam empedu yang baru, sehingga terjadi penurunan kadar kolesterol dalam darah (Kusharto, 2006). Hal ini tidak sejalan dengan penelitian Dewi (2015) yang mengatakan bahwa tidak ada hubungan yang signifikan ( $\mathrm{p}>0,05$ ) antara asupan serat dengan kadar kolesterol pada pasien PJK rawat jalan di RSUD Dr. Moewardi, dalam penelitiannya dijelaskan bahwa tidak adanya hubungan itu dimungkinkan karena sebagian besar subjek yang menjadi sampel telah melakukan konsultasi dan pengobatan rawat jalan dengan rutin selama lebih dari 2 tahun.

\section{Pengaruh Pemberian Es Krim Ubi Jalar Ungu Terhadap Tekanan Darah}

Hasil analisa bivariat dengan jumlah responden sebanyak 28 orang menunjukkan hasil bahwa rata-rata tekanan darah responden dalam penelitian ini juga mengalami penurunan. Hal ini bisa saja disebabkan karena terjadinya penurunan kadar kolesterol total dalam darah responden. Hal ini sesuai dengan teori terjadinya hiperkolesterolemia, dimana hiperkolesterolemia merupakan faktor resiko terjadinya hipertensi yang diawali dengan proses aterosklerosis pada pembuluh darah akibat terbentuknya gel busa (Arthur dan Jhon( 2008) dalam (Kadri dkk, 2014).

Kadri,dkk (2014) menyebutkan bahwa responden dengan kadar kolesterol tidak normal banyak yang mengalami hipertensi. Setelah diberikan intervensi, tekanan darah 
diastolik pada beberapa responden mengalami penuruan dan dalam penelitian ini terbukti bahwa dari 30 responden yang diteliti, ada sebanyak $93 \%$ responden atau sebanyak 28 orang yang mengalami tekanan darah diastolik diatas normal.

Tekanan darah responden diukur sebanyak 4 kali selama penelitian ini berlangsung. Terjadi penurunan rata-rata tekanan darah sebelum diberikan intervensi adalah $84,73 \mathrm{mmHg}$ dan setelah diberikan intervensi mengalami penurunan sebanyak 2,5\% menjadi $82,60 \mathrm{mmHg}$. Hal ini sesuai dengan penelitian Jawi dan Yasa (2012) yang mengatakan ada pengaruh pemberian ekstrak air ubi jalar ungu terhadap tekanan darah hanya saja dalam penelitiannya tidak dijelaskan berapa persen penurunan yang terjadi. Hasil penelitian Loo,dkk (2016) di Finlandia juga menyebutkan bahwa pemberian buah Chokeberry yang mengandung antosianin dapat menurunkan tekanan darah diastolik pada siang hari sebanyak $-1,64 \mathrm{mmHg}$ dengan nilai $\mathrm{p}=$ 0,02 , dan pada keadaan normal sebanyak $1,62 \mathrm{mmHg}(\mathrm{p}=0,057)$ dan tekanan darah selama 24 jam sebanyak $-1,07 \mathrm{mmHg}(\mathrm{p}=$ $0,084)$.

Hasil penelitian ini mendukung teori dan penelitian-penelitian dengan ekstrak yang mengandung antosianin dari berbagai sumber dan dapat menurunkan tekanan darah melalui mekanisme mempertahankan fungsi endotel melalui peningkatan NO, karena antosianin dapat sebagai antioksidan sehingga dapat mengatasi stress oksidatif (Jawi dan Yasa, 2012).

Berdasarkan hasil penelitian ini menunjukkan bahwa secara statistika terdapat pengaruh pemberian es krim ubi jalar ungu terhadap kadar kolesterol total dan tekanan darah pasien hiperkolesterolemia, meskipun belum diketahui secara pasti pengaruhnya karena bisa saja peningkatan atau penurunan kadar kolesterol disebabkan karena produksi kolesterol dalam tubuh responden itu sendiri (faktor herediter), atau karena faktor lainnya.

\section{Keterbatasan Penelitian}

Penelitian ini menggunakan metode pre eksperimental untukmengetahui pengaruh pemberian es krim ubi jalar ungu terhadap kadar kolesterol total dan tekanan darah pasien hiperkolesterolemia. Dalam penelitian ini responden tidak diberikan diit khusus dengan pola konsumsi yang sama. Sehingga, tidak bisa digeneralisasikan bahwa penurunan kadar kolesterol total maupun tekanan darah itu disebabkan oleh pemberian es krim ubi jalar ungu.

Selama penelitian ini berlangsung, terdapat 2 minggu jalannya penelitian yang bertepatan dengan puasa. Sehingga asupan makanan tiap-tiap responden mengalami perubahan. Selain itu juga terdapat beberapa faktor lain yang dapat 
mempengaruhi kadar kolesterol dan tekanan darah, antara lain : faktor herediter, lingkungan, jenis kelamin, aktivitas fisik, konsumsi makanan sehari-hari, kebiasaan meroko, dan faktor-faktor lainnya dimana tidak semua faktor-faktor dapat diteliti lebih lanjut oleh peneliti.

\section{KESIMPULAN}

Rata-rata kolesterol total responden sebelum intervensi adalah 226,43 $\mathrm{mg} / \mathrm{dl}$, sedangkan untuk tekanan darah sebelum intervensi adalah $84,73 \mathrm{mmHg}$. Setelahdiberikanintervensirata-rata kadar kolesterol responden menjadi 224,23 $\mathrm{mg} / \mathrm{dl}$ atau sebanyak 2,2 mg/dl. Dan pada tekanan darah juga terjadi penurunan menjadi 82,60 mmHg atau sebanyak 2,13 mmHg.Rata-rata asupan serat responden mengalami penurunan sebanyak 1,1 gr selama 28 hari penelitian. Sedangkan rata-rata konsumsi asupan kolesterol dalam makanan responden mengalami peningkatan

\section{DAFTAR RUJUKAN}

Bintanah, S. \& Handarsari, E. 2012. Asupan Serat dengan Kadar Gula Darah, Kadar Kolesterol Total dan Status Gizi Pada Pasien Ddiabetus Mellitus Tipe 2 di Rumah Sakit Roemani Semarang. PROSIDING SEMINAR NASIONAL.

Bintanah, S. \& Muryati 2010. Hubungan Konsumsi Lemak Dengan Kejadian Hiperkolesterolemia Pada Pasien Rawat Jalan Di Poliklinik Jantung Rumah Sakit Umum Daerah Kraton Kabupaten Pekalongan. Jurnal Kesehatan Masyarakat Indonesia.

Budiasa, K. \& Jawi, I. M. 2011. Ekstrak Air Umbi Ubijalar Ungu Menurunkan Total Kolesterol sebanyak 1 mg. Hal ini dikarenakan responden tidak diberikan diit khusus sehingga asupan makanan responden tidak dibatasi. Berdasarkan hasil uji t-test dependen terdapat pengaruh pemberian es krim ubi jalar ungu terhadap kadar kolesterol total dengan nilai $\mathrm{p}=0,021<$ 0,05.Pada pemeriksaan tekanan juga terdapat perubahan tekanan darah responden setelah diberikan intervensi $(\mathrm{p}=0,001<0,05)$.Tetapi belum diketahui secara pasti perubahan kadar kolesterol dalam darah disebabkan karena pemberian es krim ubi jalar ungu atau karena faktor lain yang tidak diteliti oleh penelitiDikarenakan keterbatasan peneliti sehingga dalam penelitian ini tidak semua faktor-faktor tersebut dapat diteliti.

Penelitian ini memerlukandesain penelitian eksperimentallainyang lebih tinggi tingkat validitasnya sehingga dapat memperhatikan faktor-faktor lain yang dapat mempengaruhi hasil dari penelitian.

serta Meningkatkan Total Antioksidan Darah Kelinci. Jurnal Veteriner, 120-125.

Dwi, A. N., Utami, P., Hadju, V. \& Masni 2015. Pengaruh Pemberian Kapsul Ubi Jalar Ungu Terhadap Kadal HDL dan LDL Guru Obesitas Sentral di SMPN Kota Makassar. JST Kesehatan, Vol. 6 No.1, 91-96.

Estruch, R., Martínez-González, M. A., Corella, D., Basora-Gallisá, J., Ruiz-Gutiérrez, V., Covas, M. I., Fiol, M., Gómez-Gracia, E., LópezSabater, M. C., Escoda, R., Pena, M. A., DiezEspino, J., Lahoz, C., Lapetra, J., Sáez, G. \& Ros, E. 2009. Effects of dietary fibre intake on risk factors for cardiovascular disease in subjects at high risk. Journal of Epidemiology and Community Health, 63, 582. 
Jawi, I. M. \& Yasa, W. P. S. 2012. Ekstrak Air Umbi Ubi Jalar Ungu Menurunkan Tekanan Darah Tikus Putih Hipertensi yang diinduksi dengan $\mathrm{NaCl}$. Jurnal Ilmiah Kedokteran.

Kadri, H., Sulastri, D. \& Feryadi, R. 2014. Hubungan Kadar Profil Lipid dengan Kejadian Hipertensi pada Masyarakat Etnik Minangkabau di Kota Padang Tahun 2012. Jurnal Kesehatan Andalas.

Loo, B.-M., Erlund, I., Koli, R., Puukka, P., Hellström, J., Wähälä, K., Mattila, P. \& Jula, A. 2016. Consumption of chokeberry (Aronia mitschurinii) products modestly lowered blood pressure and reduced low-grade inflammation in patients with mildly elevated blood pressure. Nutrition Research, 36, 1222-1230.

Mikasari, W. \& Ivanti, L. 2011. Sifat Organoleptik dan Kandungan Nutrisi Es Krim Ubi Jalar Varietas Lokal Bengkulu. Balai Pengkajian Teknologi Pertanian Bengkulu.

Noer, E. R. \& Budiatmaja, A. C. 2014. Pengaruh Pemberian Jus Buah Naga Merah (Hylrocereus Polyrhizus) Terhadap Kadar Kolesterol Total Pria Hiperkolesterolemia. Journal of Nutrition College, 655-664.

Pil, H., Jae Ho, C., Eun Hee, H., Hyung Gyun, K., Ji-Hyang, W., Kyung Ok, J., Kyung Hee, J., Kwang-il, K., Tae Cheon, J., Young Chul, C. \& Hye Gwang, J. 2011. Purple sweet potato anthocyanins attenuate hepatic lipid accumulation through activating adenosine monophosphate-activated protein kinase in human HepG2 cells and obese mice. Nutrition Research, 31, 896-906.

Samber, L. N., Semangun, H. \& Prasetyo, B. 2013. Ubi Jalar Ungu Papua Sebagai Sumber Antioksidan. Prosiding Seminar Biologi.

Sari, Y. D., Prihatini, S. \& Bantas, K. 2014. Asupan Serat Makanan dan Kadar Kolesterol-LDL Penduduk Berusia 25-65 Tahun di Kelurahan Kebon Kalapa, Bogor. Penelitian Gizi dan Makanan (The Journal of Nutrition and Food Research), 37, 51-58.

Setyaningsih, A. \& Pramono, A. 2013. Pengaruh Pemberian Snack Bar Kedelai Terhadap Kadar Kolesterol Ldl Dan Hdl Wanita Hiperkolesterolemia. Diponegoro University.

Turner, N. D. \& Lupton, J. R. 2011. Dietary Fiber. Advances in Nutrition, 2, 151-152.

Waloya, T., Rimbawan \& Andarwulan, N. 2013. Hubungan Antara Konsumsi Pangan can Aktivitas Fisik dengan Kadar Kolesterol Darah Pria dan Wanita Dewasa di Bogor. Jurnal Gizi dan Pangan, 9.

WHO. 2015. Noncommunicable diseases [Online]. Available:

http://www.who.int/mediacentre/factsheets/fs3 55/en/ [Accessed 20 February 2017] 